\title{
Is Medieval French diglossic? New evidence on remnant V2 and register
}

\section{Pierre Larrivée}

Université de Caen Normandie

Pierre.Larrivee@unicaen.fr

Received: 15-03-21

Accepted: 30-09-21

Published: 22-02-2022

How to cite: Pierre Larrivée. 2022. Is Medieval French diglossic? New evidence on remnant V2 and register. RLLT17, eds. Ora Matushansky, Laurent Roussarie, Michela Russo, Elena Soare \& Sophie Wauquier. Special issue of Isogloss Open Journal of Romance Linguistics 8(2)/8, 1-16.

DOI: https://doi.org/10.5565/rev/isogloss. 114

\begin{abstract}
An ongoing debate concerns the degree of diglossia of contemporary French, by which vernacular and normative registers display significant grammatical differences. Was diglossia characterizing Medieval French? This question is explored through the study of unambiguous V2 configurations. The word order has been shown to display rates of use and informational behavior correlating to register. The correlation is investigated in novel data relating to narration $v s$. dialogue and to correspondence by members of different social classes. Quantitative analysis shows that variation in V2 behavior remains determined by formality. The proposed methods thus help measure diglossia of previous states of languages.
\end{abstract}

Keywords: diglossia, register, Medieval French, V2, dialogue, correspondence. 


\section{Introduction}

A language like French has been described as diglossic because it has a number of grammatical features that have differential realizations and behavior in the vernacular and in the normative practice (Massot 2010, Zribi-Hertz 2011, Rowlett 2013). The question is whether this is a new state of affair, or whether it was always thus. Answering that question is difficult because the available resources representing vernacular exchanges are few, and become fewer still the further one goes back in time. Reconstructing vernacular grammar therefore relies on developing efficient methods.

Two methods are operationalized here. One is to compare narration and dialogue parts of $13^{\text {th }}$ century prose texts. The second is to consider the productions of members of different social classes in $15^{\text {th }}$ century correspondence. The sources are used to analyze the issue of one construction unambiguously instantiating verb-second word order in Medieval French. The analysis confirms that this declining word order configuration was already sensitive to register, and that in this respect Medieval French had features of a diglossic language.

\section{Background}

Diglossic languages display significant grammatical differences between vernacular and normative registers (defined as a continuum of distance along the lines of Koch \& Oesterreicher 2001). Thus some syntactic phenomena are part of the immediate competence of speakers, and some are found in normative practice. An example is provided by post-verbal use of nominative clitics in French (known as 'subject inversion'). Such uses are absent from vernacular productions of contemporary speakers (Blanche-Benveniste 1997 : 54, Culberston and Legendre 2008, Palasis 2013) who acquire it latter with a second-language level of command (Meisel, Elsig and Bonnesen 2011). This feature illustrates the diglossia of contemporary French, such that clitic subject inversion is exclusively a normative practice, and therefore not part of the ordinary competence of speakers.

Reconstructing the ordinary competence of speakers for earlier states of languages ${ }^{1}$ can only be achieved from traces of written practice. Finding texts that reveal vernacular practice thus appears crucial. Such texts tend to belong to certain types, as proposed by Lodge (2009: 212) and Ayres-Bennett (2020). Ayres-Bennett considers ego-documents (letters, diaries, travelogues) and represented speech, especially dialogue as compared to other textual modalities. The rate and behavior of grammatical features in dialogue and narration parts of the same text have been contrasted by a number of authors (Vance 1997: 245-246, Schøsler 2002, Rodríguez Somolinos 2003, Marnette 2006, Dufter 2010). Such comparisons have also been encouraged by the latter work on "represented orality" in literary texts (Marchello-Nizia 2012, Guillot et al. 2015, Guillot-Barbance et al. 2017, Lefeuvre \& Parussa 2020). These studies have contributed to establish that dialogue is generally less conservative than narration (Glikman \& Mazziotta 2014, Mazziotta \& Glikman 2019; see also Donaldson 2018). As compared to narrative sequences, dialogue tends to contain a

$1 \quad$ For an early, erudition-based study of Medieval Wallonia, see Remacle (1948). 
lower rate of declining features, and a higher rate of emerging features. The advantage of such of method is that one can compare different modalities within the same text, although it does not always yield the expected results (Steiner 2014, Pujol 2020), especially when not based on representation of real-life speech. On the other hand, Medieval records of actual dialogues presented in direct speech are exceedingly rare. Some exceptional resources are represented by the Old Bailey Corpus and the Salem Witch Trial for English, the Lio Mazor for Venetian and the Anglo-Norman Year Book Corpus for (Anglo-Norman) French, but they offer a limited temporal coverage, from 1720 to 1913 for the first, 1692-1693 for the second, 1312-1314 for the third, and 1280 to 1385 for the latter. Work based on the Year Books shows that they are less formal than e.g. petitions (Ingham 2016, Larrivée in press), and that accordingly they contain a lesser proportion of declining verb-second word order, but there has been no attempt to contrast narration and dialogue. As before, the expectation would be that dialogue should be less conservative than narration.

Another approach is to compare the speech, real or fictitious, of members of different social classes. While members of different social classes can adopt both vernacular and normative traits, there is an expectation that more vernacular registers will be used more by members of less privileged social groups. Such a comparison of class membership and register crucially relies on these dimensions being represented in a given text. This is the case in the 1422 prose allegory Quadrilogue invectif, which presents in turn speakers from different social orders, including a character meant to represent the people. Schøsler (2002) shows that the latter uses fewer null subjects than the representative of the clergy and of the knighthood. As expected, declining features are less represented in the vernacular practice, which is associated more readily to members of less privileged social groups.

Quantitative studies of dialogue and of correspondence are proposed in this paper. The method is applied to a declining configuration found in Medieval French. Verb-second word order (V2) is a configuration in which the verb follows an initial projection (XP) (Wolfe 2018 and references therein). Crucially, since Skårup (1975), Thiersch (1978) and den Besten (1982), both the initial XP and the verb are generally assumed to be in a high syntactic position, later identified as the left periphery. This is demonstrated by unambiguous configurations where the XP is a projection other than the subject, be it an argument or adjunct as in (1), a particle or connector as in (2) or a coordinator (3), that with the verb stands above the expressed subject. These are illustrated by the following examples from the beginning of $13^{\text {th }}$ century prose literary text Queste del Saint Graal.

$\begin{array}{lll}\text { ce sai } & \text { ge } & \text { bien } \\ \text { this know.PR.1s } & \text { 1S.NOM } & \text { well } \\ \text { This I know well } & & \end{array}$

Einsi parolent li dui frere

de Galaad

Thus speak-PR.3P the.NOM two brother.P of Galaad

Thus the two brothers were speaking of Galaad

$$
\begin{array}{lll}
\text { et } & \text { est } & \text { li chevaliers } \\
\text { and } & \text { be.PR.3SPR } & \text { the.NOM knight.NOM }
\end{array}
$$

And the knight is such a young man

si juenes hons

such young man 
A number of recent studies have sought to characterize the trajectory and characteristic properties of Medieval French V2 at a period when it is being lost as a productive configuration. There is however considerable variance between the studies. Work on $13^{\text {th }}$ century literary prose cite figures of between $17 \%$ and $30 \%$ of V2 among all clauses (Radwan 2011, Salvesen and Bech 2014, Marchello-Nizia 2018, Kaiser and Zimmermann 2011), $13^{\text {th }}$ century prose legal sources yield $3.7 \%$ of unambiguous V2 (Larrivée 2019). Such quantitative variance between literary and non-literary sources is also found across the history of Portuguese, Galves 2019. As for the informational value of the XP that is thought to play an important role for the construction, whereas Larrivée (2019) and Ingham (2018) converge in finding virtually categorical discourse-old argument and adjunct XPs with unambiguous V2 in $13^{\text {th }}$ century prose, Labelle and Hirschbühler (2018) discover a near-categorical discourse-new Focus value for preverbal objects in verse texts between 1090 and 1200, and Radwan no specific value for V2 in 13th century literary prose. These issues are important because the former tells us whether V2 is a central word order of $13^{\text {th }}$ century French or merely a particular construction, as is the case in contemporary normative French (Guimier 1997); and the latter because it indicates whether the configuration is driven by formal syntactic requirements or informational dynamics. The hypothesis is that such variance relates to the register of the investigated texts, as suggested by Ingham $(2012: 114,117)$ and Ledgeway (2008) and documented by Larrivée (2019).

The role of register on rate of use and informational value for $\mathrm{V} 2$ configurations in Medieval French is verified using two complementary methods of examining narration vs. dialogue, and productions of socially-differentiated writers in correspondence. The first investigation is presented in the next section.

\section{3. $\mathrm{V} 2$ in narration and dialogue in $13^{\text {th }}$ century legal and literary prose}

The purpose of this section is to examine the behavior of Medieval French V2 in narration and dialogue. While the influence of text formality on rates of use of V2 has already been established by Larrivée (In press), the comparison of narration and dialogal has not been attempted. One reason to do such a comparison is that it might explain the variance in informational values associated to the argument and adjunct XPs of V2 across studies. Whereas Radwan finds that $49 \%$ of XP in unambiguous V2 configuration are discourse-new in a $13^{\text {th }}$ century literary text, Larrivée (2019) shows that $2,7 \%$ are in legal Norman texts from 1150 to 1250 . It may be that literary texts contain more dialogue, and that this provides more opportunities to introduce discoursenew information, including of the Focus type. If this is correct, the expectation is that dialogue should contain more discourse-new and more Focus XPs than narration, and that for reasons of formality more such XPs are found in literary than legal texts.

To optimize comparability, the research is contrasting two of the texts used by Larrivée (In press) that contain both direct speech dialogue on the one hand, and on the other reported speech and narration. The Anglo-Norman legal prose Year Books represent notes from actual cases at the King's court, from which the earliest 1270s texts are used (Brand 1996). The literary prose Queste del Saint Graal is a romance dating from 1225-30 and presenting no particular regional trait. These are used to 
identify examples of main clause ${ }^{2}$ unambiguous $\mathrm{V} 2$ in dialogue as compared to other modalities ("narration" from now on refers to both narration and indirect speech). Again, unambiguous V2 are structures such as those illustrated in (1)-(3) with an expressed postverbal subject and a preverbal XP, and although it was not possible to consider exclusively the strict cases with only one XP, these were separated in data reported below.

A continuous sequence of each text was annotated that contained 50 unambiguous main clause V2 constructions in direct speech and 50 in narration, starting from $\S 7$ to end $\S 48$ in Queste, and from p. 9 to p. 45 in the Year Book. A full analysis of all the clauses in the sequence necessary to obtain the target number of V2 was not accomplished, as the proportion of V2 per clause is already provided in Larrivée (In press) for the first $50 \mathrm{~V} 2$ across modalities $(5.1 \%$ of all clauses and $14 \%$ of all main clauses in the Year Books and $9.2 \%$ of all clauses vs. $20.7 \%$ of all main clauses in the Queste), and since the distribution of direct speech is text-dependent. What was identified was first the type of XP, arguments and adjuncts (1) on the one hand, and on the other particles such as ainsi 'thus' in (2) and coordinators like et 'and' (3). While the former has an informational value, that is not the case of the latter: there is no situation in which one can identify discourse-old coordinators as opposed to discourse-new or Focus coordinators. As the objective of this study is to assess whether there is a significant relation between the language modality of narration and dialogue and the informational value of the initial XP, what was counted was the value of the initial XP. The criteria to determine that value were those used in Larrivée (In press). Discourseold XPs are those that relate to information previously made available, via e.g. a deictic/anaphoric expression as in (1) above. No relation to the antecedent context is entertained by discourse-new XPs, and among them, Focus implies a contrast to other potential values (see the illustrations provided below). The results from the analysis are as follows. We start with the data from the less formal text, the Year Books. Results ${ }^{3}$ from dialogue is presented in Table 1, and those from narration in Table 2.

Table 1. Informational value of XPs in Year Book dialogue

\begin{tabular}{|l|l|l|l|c|c|c|}
\hline & \multicolumn{9}{|l}{} & \multicolumn{2}{l|}{ XP } & Totals V2 \\
\hline & Argument and adjuncts & \multicolumn{2}{l|}{$\begin{array}{l}\text { Particles and } \\
\text { connectors }\end{array}$} & Coordinators & \\
\cline { 2 - 7 } & Old & New & Focus & & 11 & 50 \\
\hline Totals & 38 & 5 & 2 & 23 & 0 & 28 \\
\hline Strict & 15 & 2 & 1 & 10 & 11 & 22 \\
\hline Non-strict & 23 & 3 & 1 & 13 & & \\
\hline
\end{tabular}

Table 2. Informational value of XPs in Year Book narration

\begin{tabular}{|c|c|c|c|c|c|c|}
\hline & \multicolumn{5}{|l|}{$\mathbf{X P}$} & \multirow[t]{3}{*}{ Totals V2 } \\
\hline & \multicolumn{3}{|c|}{ Argument and adjuncts } & \multirow{2}{*}{$\begin{array}{l}\text { Particles and } \\
\text { connectors }\end{array}$} & \multirow[t]{2}{*}{ Coordinators } & \\
\hline & Old & New & Focus & & & \\
\hline Totals & 30 & 2 & 1 & 20 & 20 & 50 \\
\hline Strict & 18 & 1 & 1 & 7 & 2 & 29 \\
\hline Non-strict & 12 & 1 & 0 & 13 & 18 & 21 \\
\hline
\end{tabular}

2 Included are subordinates under bridge verbs such as say, since these are assumed to behave like main clauses.

3 In tables 1 to 4 , the number of non-strict XPs is always greater than the total number of V2, since non-strict V2 configuration have by definition at least two XPs, unlike strict V2 that have only one. 
The figures from dialogue show that discourse-old XPs are very much the dominant informational value, at $84 \%$ of the 45 adjunct and arguments, and $76 \%$ of all V2. A similar situation is found in narration, with differential numbers, at $91 \%$ of the 33 arguments and adjuncts and $60 \%$ of all V2. New and Focus XPs are better represented in dialogue, with 7 occurrences (15.5\% of arguments and adjuncts XPs and 14\% of V2), as compared to 3 in narration (10\% of the relevant XPs and $6 \%$ of V2). There is however no significant difference between Focus in narration, at 2 occurrences (4\% of XPs), as compared to 1 in narration (3\% of XPs). Strict and non-strict Focus cases in dialogue and narration are illustrated in turn.

(4) Dialogue - strict

$\begin{array}{ll}\text { E ascune gent } & \text { diunt } \\ \text { And some people } & \text { say.PR.3P }\end{array}$

ke ben pet yl (scilicet tenens) dedire

that well can.PR.3s 3S.NOM (scilicet tenens) deny

And some people say that he can well retract himself

(5) Dialogue - non-strict

Si ascun bastard eyt purchase ascun tenement [...]

If some bastard have.SUBJ.3s buy.PTCP some piece-of-land

ben se porreyt le chef seygnur apres la mort cely bastard

well REFL can.COND.3s the chief lord after the death this bastard

entrer en le tenement mes nemye en ceu cas.

enter in the piece-of-land but not in this case

If a bastard had purchased a piece of land, the lord could well gain it after his death, but not in this case

(6) Narration - strict

$\mathrm{W}$ de N. et les autres parceners [...] dyent

$\mathrm{W}$ de $\mathrm{N}$. and the other co-owners say.PR.3P

$\begin{array}{llll}\text { ke atort } & \text { porte } & \text { yl } & \text { ceste assise } \\ \text { that wrongly } & \text { bear.PR.3S } & \text { 3S.NOM } & \text { that assize }\end{array}$

$\mathrm{W}$ de $\mathrm{N}$. and the other co-owners say that he wrongly stands in assize

We now turn to the more formal, literary text. The results from dialogue are presented in Table 3, and those from narration in Table 4. 
Table 3. Informational value of XPs in Queste dialogue

\begin{tabular}{|c|c|c|c|c|c|c|}
\hline & \multicolumn{5}{|l|}{$\mathbf{X P}$} & \multirow[t]{3}{*}{ Totals V2 } \\
\hline & \multicolumn{3}{|c|}{ Argument and adjuncts } & \multirow{2}{*}{$\begin{array}{l}\text { Particles and } \\
\text { connectors }\end{array}$} & \multirow[t]{2}{*}{ Coordinators } & \\
\hline & Old & New & Focus & & & \\
\hline Totals & 23 & 4 & 7 & 25 & 13 & 50 \\
\hline Strict & 12 & 3 & 3 & 10 & 2 & 30 \\
\hline Non-strict & 11 & 1 & 4 & 15 & 11 & 20 \\
\hline
\end{tabular}

Table 4. Informational value of XPs in Queste narration

\begin{tabular}{|l|c|c|c|c|c|c|}
\hline & \multicolumn{9}{|l}{ XP } & \multicolumn{2}{l|}{ Totals V2 } \\
\hline & Argument and adjuncts & \multicolumn{2}{l|}{$\begin{array}{l}\text { Particles and } \\
\text { connectors }\end{array}$} & Coordinators & \\
\cline { 2 - 5 } & Old & New & Focus & & 20 & \\
\hline Totals & 26 & 0 & 9 & 25 & 9 & 26 \\
\hline Strict & 8 & 0 & 8 & 9 & 1 & 24 \\
\hline Non-strict & 18 & 0 & 1 & 9 & 19 & 26 \\
\hline
\end{tabular}

The numbers from dialogue show that discourse-old XPs account for $68 \%$ of argument and adjunct XPs and $46 \%$ of all V2. Similarly, $74 \%$ of relevant XPs and $72 \%$ of V2 are discourse-old in narration. New and Focus XPs are comparable in proportion across modalities, with dialogue represented by $32 \%$ of all relevant XPs and $22 \%$ of V2 and narration by $26 \%$ and $18 \%$. This is strikingly higher than what is found in the legal text. Also strikingly higher is the figure for Focus alone, which is more numerous than the discourse-new in both modalities, and the only status represented in narration. Dialogue provides $21 \%$ of relevant XPs with a Focus, and narration $26 \%$, more than 5 and 8 times the proportion in the legal text.

(7) Dialogue - strict

$\begin{array}{llll}\text { Assez } & \text { le } & \text { savra } & \text { l'en } \\ \text { Enough } & \text { 3SG.ACC } & \text { know.FUT.3s } & \text { 3s.NOM }\end{array}$

encore tout a tens

again all at time

People will know it enough for all times

(8) Dialogue - non-strict

Mes de tant sont il engignié

But of so-much be.PR.3P 3S.NOM fooled

But they are fooled by so much

(9) Narration - strict

Et distrent que bien fust il venuz

And say.PST.3P that well be.PST.3s 3S.NOM come.PTCP

And they said that he did well to come 
(10) Narration - non-strict

$\begin{array}{lll}\begin{array}{l}\text { Au matin } \\ \text { In morning }\end{array} & \begin{array}{l}\text { si tost come li jorz } \\ \text { so early as the day }\end{array} & \begin{array}{l}\text { aparut }^{4} \\ \text { appear.PST.3SG }\end{array} \\ \text { Se leverent } & \text { li } & \text { compaignon } \\ \text { REFL rise-up.PST.3P } & \text { the.NOM } & \text { companions }\end{array}$

In the morning as soon as the day rose the companions rose up

A summary of proportions across texts and modalities is presented below.

Table 5. Rates of informational values per language modality in two $13^{\text {th }} \mathrm{c}$. texts

\begin{tabular}{|l|l|l|l|l|l|}
\hline & Arguments and adjuncts & & Total V2 \\
\hline & Discourse-old & $\begin{array}{l}\text { Discours-new and } \\
\text { Focus }\end{array}$ & Focus & Totals & \\
\hline Dialogue YB & $38 / 84 \%$ & $7 / 16 \%$ & $2 / 4 \%$ & $45 / 90 \%$ & 50 \\
\hline $\begin{array}{l}\text { Dialogue } \\
\text { Queste }\end{array}$ & $23 / 68 \%$ & $11 / 32 \%$ & $7 / 21 \%$ & $34 / 68 \%$ & 50 \\
\hline Narration YB & $30 / 91 \%$ & $3 / 9 \%$ & $1 / 3 \%$ & $33 / 67 \%$ & 50 \\
\hline $\begin{array}{l}\text { Narration } \\
\text { Queste }\end{array}$ & $26 / 74 \%$ & $9 / 26 \%$ & $9 / 26 \%$ & $35 / 72 \%$ & 50 \\
\hline
\end{tabular}

The differential in rates of use of Focus is following expectations regarding formality there are fewer Focus in the less formal texts, that is 3 in the Year Books out of $100 \mathrm{~V} 2$, as compared to 16 out of a 100 in the literary Queste. The expectations are not confirmed with respect to modality: there are actually fewer Focus in dialogue (with 9 occurrences across the two texts) than in narration (with 10 occurrences). It is only in the less formal text that mode has the expected impact, where although only a handful of cases are concerned, there are more Focus in dialogue than in narration. The fact that there are actually fewer Focus in dialogue than in narration in the Queste appears an unexpected result that supports the view that literary material might not best reflect the effective grammar of a period. The investigation therefore shows that V2 is sensitive to register, and that the dialogue $v s$. narration dimension has only an impact on rates of Focus in real-life exchanges. This correlation is examined from a different angle in the next section.

\section{Register and social classes at the end of the $15^{\text {th }}$ century}

This section reports on a second investigation regarding the correlation between register and V2 configuration. It differs from the previous investigation in that it does not rely on the differential profile of dialogue as compared to narration. Instead, it investigates the differentiation in the productions of members of different social classes. These productions are real-life exchanges, as reproduced in the Year Books and unlike in the fictional literary text, a potentially fruitful choice as suggested by the unexpected

$4 \quad$ A reviewer questions whether si tost come contains an element of degree, being a set phrase. Yet, as far as we can tell, the phrase indicates a high degree of rapidity (as soon as), that contrasts with an ordinary indication of temporality (when). As expressions of degree are primary candidates for Focus, I have analyzed them as such here. 
behaviors evidenced by the latter. The selected material is correspondence found from an early set of letters from a noble Norman family. The correspondence of the d'Estouteville family is exceptional in preserving letters both from the members of the family and from some of their employees (a horseman, a bricklayer, a servant, a butler). Although these letters are from a comparatively late period from 1460-1535, that period is certainly amongst the earliest for French when private letters include correspondence from lower social class members. Such data thus in principle allows an examination of whether members of each social class has a differentiated language practice. If so, this would lead one to expect, in view of the results of the previous section, that as a feature marked by register, $\mathrm{V} 2$ would be more present in the letters by noble writers than by their employees.

The method of investigating V2 with respect to the social class of the writer was defined as follows. First, we selected letters from the 1460 and 1480 period, to avoid significant impact of temporal change by going into the first quarter of the $16^{\text {th }}$ century. In that period a selection was operated in function not only of the social class of their writer (which we schematically termed High and Low), but also of the recipient. A quadrant of letters was thus defined from High to High, from High to Low, from Low to High and Low to Low. The repartition was as follows, with the number of the letters referring to edition by Le Cacheux (1935).

Figure 1. d'Estouteville letters by social class of writer and recipient

\begin{tabular}{|l|l|l|}
\hline & High recipient & Low recipient \\
\hline High writer & XXV-XXX & I, VIII, XI, XIV \\
\hline Low writer & II, IX, XV, XIX & XVII, XVIII \\
\hline
\end{tabular}

Using the digital version of the letters from the EPELE corpus, each clause was annotated for status of clause, realization and position of subject, as previously. The results are summarized in the following table.

Table 6. Number of V2 clauses in d'Estouteville letters

\begin{tabular}{|l|l|l|l|l|l|}
\hline & Low-Low & Low-High & High-Low & High-High & Totals \\
\hline V2 clauses & 0 & 4 & 0 & 7 & 11 \\
\hline Total clauses & 52 & 87 & 83 & 219 & 441 \\
\hline
\end{tabular}

The numbers show clearly that V2 is a rare configuration at $2,5 \%$ of all clauses.

We provide the illustrations below.

(11) Low-High

a. Et veu ces termes,

And see.PTCP these terms,

monstrent bien

show.PR.3P well

lesdictz officiers qu' ils

n'ont

the said officers that 3P.NOM

NEG have.PR.3P

nul bon voulloir

none good want.INF

(IX, Low to High) 
And given these terms, the said officers clearly show that they have no good will

b. et trouva Clement ung cerf aux buisson de Pissecat (XXI, Low to High) and find.PST.3S Clement a stag at-the bushes of Pissecat And Clement found a stag in the bushes of Pissecat

c. et chasseront vos chiens tres bien (XXI, Low to High) and hunt.FUT.3P your dogs very well

And your dogs will hunt very well

d. et aussi sont tous messieurs vos enffans and so be.PR.3P all misters your children and so are all your children

(12) High-High

a. et a fait mondit sieur d'Orleans trente lieues (XXVI, High to High) and have.PR.3s do.PTCP my-said Lord of Orleans thirty miles and the said Lord of Orleans has done thirty miles

b. et est le duc sur ses piés, and be.PR.3s the duke on his feet, and the Duke is on his feet

c. et luy ont promis tous and 3S.DAT have.PR.3P promise.PTCP all

[...] les seigneurs et barons de bien [...] le servir (XXVI, High to High)

the lords and barons to well 3s.ACC serve

and all the lords and barons promised to serve him well

d. encor ne sonce que menuz gens, again NEG be.PR.3P-this only small people (XXVI, High to High) and yet they are unimportant people

e. et pource sont plus esbahis and for this be.PR.3s more astonished 
ceulx de par deça que [...] (XXVI, High to High)

those of by this-side than $[\ldots]$

and because of this, those from beyond were more astoni shed than $[\ldots]$

f. et estait

avecquez moy monsieur de Brully

and be.PST.3S

with me (XXVII, High to High)

and Mr. de Brully was with me mister de Brully

g.

$\begin{array}{ll}\text { et veira } & \text { l'en } \\ \text { and see.FUT.3s } & \text { 3S.NOM }\end{array}$

ce $\mathrm{qu}^{\prime} \quad$ il $\quad$ a $\quad$ receu

this REL.ACC 3S.NOM have.PR.3S receive.PTCP

and we will see what he has received

Although the number of occurrences is lower than one would wish due to the extreme rarity of Medieval correspondence produced by members of lower social-classes, there are twice as many occurrences produced by higher social-class writers as there are by lower social-class writers. But this is not reflective of a significant difference, as the V2 represent a proportion of $4,6 \%$ of all clauses in each group. What is significant is the productions not by writers but by recipients. All of the eleven occurrences of V2 are found in letters written to members of higher social classes, and none in letters addressed to lower social-class members.

The results of the analysis of this exceptional resource of socially-differentiated correspondence are revealing clear and unexpected results. A priori, if V2 is a registersensitive grammatical feature, one would have expected it to be found mostly in productions from writers of higher social classes. That is the case, but it is not the most striking behavior. What is most striking is that V2 is found only in letters addressed to members of the higher social class. This shows clearly that audience design is defining here the usage of a grammatical feature known to be sensitive to register. Let us now move to the conclusion of this and the previous investigation.

\section{Is Medieval French a diglossic language?}

This paper proposes two methods to assess the sensitivity of syntactic configurations to register. Contrasting syntactic behavior in narration vs. dialogue on the one hand and looking at the correspondence of members of different social classes reveal that unambiguous V2 is sensitive to formality. The precise impact of formality can further be assessed. The formality of literary texts defines a higher proportion of Focus XPs, which are as much as 8 times more frequent than in the legal text. Dialogue has an effect, and a marginal one, only in the legal text. The role of formality is again found in correspondence, but with a twist: it is not the social class of the writer that defines the rate of $\mathrm{V} 2$, but that of the recipient. 
Of note are the role of audience design in the correspondence, and the unexpected results in the literary text. In the latter, there is actually a smaller proportion of Focus in dialogue than in the narration. The narration of the literary text has a massive overrepresentation of Focus XP in strict main-clause V2 configurations; if this carries to other texts, given that strict main clauses are thought to be central to V2 and that literary narration is traditionally very much the primary material of studies, that may have been instrumental in supporting the view that even in 1230 , there was no dominant informational value for the XP (but see Larrivée 2019).

This study thus confirms that V2 configurations are sensitive to register in Medieval French. This can be interpreted in two different ways. One is that V2 is an option that is on the way out, and maintained longer in more conservative higher registers. Another is that it has never really been a feature of the ordinary competence of speakers, and only ever of higher registers. At this stage, it is difficult to see how these could be apportioned. Judging by the correspondence, what is clear is that V2 is not part of the ordinary competence of speakers by the end of the $15^{\text {th }}$ century, and that it is highly sensitive to register in the earliest periods of prose attestations. It is to be hoped that more data closer to the vernacular or better methods could be brought to assess the status of this and other syntactic configurations.

\section{References}

Sources

Brand, Paul A. 1996. The Earliest English Law Reports. Volume I. London: The Selden Society.

Ingham, Richard \& Pierre Larrivée. 2010. Narrations et Dialogues en français ancien: The Anglo-Norman Year Books Corpus. Birmingham

Larrivée, Pierre et Mathieu Goux. 2018. L'écriture des peu lettrés : français vernaculaire dans la normandie médiévale https://www.unicaen.fr/epele//accueil

Le Cacheux, Paul. 1935. Correspondance de la famille d'Estouteville (1460-1535). Rouen: Lestringant.

Studies

Ayres-Bennett, Wendy. 2020. Syntaxe de l'oral. In Christiane Marchello-Nizia, Bernard Combettes, Sophie Prévost, Tobias Scheer (eds), Grande grammaire historique du français, 1466-1479. Berlin: De Gruyter. https://doi.org/10.1515/9783110348194

Blanche-Benveniste, Claire. 1997. Approches de la langue parlée en français. Paris: Ophrys. https://doi.org/10.1017/s0959269500000600

den Besten, Hans. 1983. On the interaction of root transformations and lexical deletive rules. In Werner Abrahams (ed.), On the formal syntax of the Westgermania, 47131. Amsterdam: Benjamins. https://doi.org/10.1075/la.3.03bes 
Culberston, Jenny \& Géraldine Legendre. 2008. Qu'en est-il des clitiques sujet en français oral contemporain? Congrès mondial de linguistique française. Paris: CMLF. https://doi.org/10.1051/cmlf08308

Donaldson, Brian. 2018. Diachronie de la négation phrastique en français: apports d'une approche sociohistorique Canadian Journal of Linguistics 63,2: 221-241. https://doi.org/10.1017/cnj.2017.46

Dufter, Andreas. 2010. Subordination et expression du sujet en ancien français. In Maria Iliescu, Heidi M. Siller-Runggaldier \& Paul Danler (eds). Actes du XXVe Congrès International de Linguistique et de Philologie Romanes, Innsbruck, 3-8 septembre 2007, 443-458. Berlin \& New York: de Gruyter. https://doi.org/10.1515/9783110231922.2-443

Galves, Charlotte. 2019. V2 in the history of Portuguese - a corpus-based study. Presentation, SLE, Leipzig.

Glikman, Julie \& Nicolas Mazziotta. 2014. Représentation de l'oral et structures syntaxiques dans la prose de la Queste del saint Graal (1225-1230). In Dominique Lagorgette \& Pierre Larrivée (eds), Représentation du Sens Linguistique $V$, 43-64. Chambéry: Université de Savoie. https://doi.org/10.3917/dbu.bouch.2007.01.0293

Guillot, Céline, Serge Heiden, Alexei Lavrentiev \& Bénédicte Pincemin. 2015. L'oral représenté dans un corpus de français médiéval $(9 \mathrm{e}-15 \mathrm{e})$ : approche contrastive et outillée de la variation diasystémique._Les variations diasystématiques et leurs interdépendances dans les langues romanes. In Jan Lindschouw \& Kirsten Jeppesen-Kragh (eds), Actes du colloque DIA II à Copenhague (19-21 nov. 2012), Travaux de Linguistique Romane. 15-27. https://doi.org/10.1515/zrp$\underline{2017-0011}$

Guillot-Barbance, Céline, Bénédicte Pincemin \& Alexei Lavrentiev. 2017. Représentation de l'oral en français médiéval et genres textuels. Langage 208: 53-68. https://doi.org/10.3917/lang.208.0053

Guimier, Claude. 1997. La place du sujet nominal dans les phrases . adverbe initial. In Catherine Fuchs (ed.), La place du sujet en français contemporain, 43-96. Louvain-la-Neuve: Duculot. https://doi.org/10.4000/praxematique.2865

Ingham, Richard. 2012. The transmission of Anglo-Norman: Language history and. language acquisition. Amsterdam \& Philadelphia: Benjamins.

Ingham, Richard. 2016. Investigating language change using Anglo-Norman spoken and written register data. Linguistics 54,2: 381-410. https://doi.org/10.1515/ling$\underline{2016-0004}$

Ingham, Richard. 2018. Topic, Focus and null subjects in Old French. Canadian Journal of Linguistics 63,2: 242-263. https://doi.org/10.1017/cnj.2017.48 
Kaiser, Georg A. \& Michael Zimmermann. 2011. On the decrease in subject-verb inversion in French declaratives. Esther Rinke \& Tanja Kupisch (Eds.). The Development of grammar: Language acquisition and diachronic change: In honour of Jürgen M. Meisel, 355-381. Amsterdam \& Philadelphia: Benjamins. https://doi.org/10.1075/hsm.11.19kai

Koch, Peter and Wulf Oesterreicher. 2001. Gesprochene Sprache und geschriebene Sprache / Langage parlé et langage écrit. In G. Holtus, M. Metzeltin \& Ch. Schmitt (eds), Lexikon der Romanistischen Linguistik, Bd. I/2, 584-627. Tübingen: Niemeyer. https://doi.org/10.1515/9783110938371.584

Labelle, Marie \& Paul Hirschbühler. 2018.Topic and focus in Old French V1 and V2 structures. Canadian Journal of Linguistics 63,2: 264-287. https://doi.org/10.1017/cnj.2017.52

Larrivée, Pierre. 2019. To be or not to be informational: Preverbal complements in Medieval French V2 configurations. Glossa 4,1: 1-19. https://doi.org/10.5334/gjgl.851

Larrivée, Pierre. In press. Wide variations in Medieval French V2 are due to register.

Ledgeway, Adam. 2008. Satisfying V2 in early Romance: Merge vs. Move. Journal of Linguistics 44,2: 437-470. https://doi.org/10.1017/S0022226708005173

Lefeuvre, Florence \& Gabriella Parussa. 2020. L'oral représenté en diachronie et en synchronie : une voie d'accès à l'oral spontané ? Langage 217: 9-21. https://doi.org/10.3917/lang.217.0009

Lodge, Anthony R. 2009. La sociolinguistique historique et le problème des données. In Sara Aquino-Weber, Dorothée Cotelli \&Andres Kristol (eds), Sociolinguistique historique du domaine gallo-roman. Enjeux et méthodologies, 199-219. Bern: Peter Lang.

https://doi.org/10.3726/978-3-0352-0146-8

Marchello-Nizia, Christiane. 2012. L'oral représenté: un accès construit à une face cachée des langues 'mortes'. In Céline Guillot, Bernard Combettes, Alexei Lavrentiev, Evelyne Oppermann-Marsaux \& Sophie Prévost (eds.), Le changement en français. Etudes de linguistique diachronique, 247-264. Bern: Peter Lang. https://doi.org/10.1515/zrp-2013-0125

Marchello-Nizia, Christiane. 2018. De SO à SV: Vers le sujet obligatoire et antéposé en français, les dernières phases d'un changement. Journal of French Language Studies 28:1-19. https://doi.org/10.1017/s0959269517000023 
Marnette, Sophie. 2006. Speech and thought presentation in French: Concept and Strategies. Amsterdam \& Philadelphia: Benjamins. https://doi.org/10.1075/pbns.133

Massot, Benjamin. 2010. Le patron diglossique de variation grammaticale en français. Langue française 168,4: 87-106. https://doi.org/10.3917/lf.168.0087

Mazziotta, Nicolas \& Julie Glikman. 2019. Oral représenté et narration en ancien français. Spécificités syntaxiques dans trois textes de genres distincts. Linx 78. https://doi.org/10.4000/linx.3151

Meisel, Jürgen, Martin Elsig \& Matthias Bonnesen. 2011. Delayed grammatical acquisition in first language development: Subject-verb inversionand subject clitics in French interrogatives. Linguistic Approaches to Bilingualism 1,4: 347390. https://doi.org/10.1075/lab.1.4.01mei

Palasis, Katerina. 2013. The case for diglossia: Describing the emergence of two grammars in the early acquisition of Metropolitan French. Journal of French Language Studies 23,1: 17-35. https://doi.org/10.1017/s0959269512000348

Pujol i Campeny, Afra. 2020. The left periphery of reported speech and reported thought in Old Catalan. Presentation, SLE.

Radwan, Sonja. 2011. L'ordre des mots en ancien français. La syntaxe et la structure informationnelle de la zone préverbale. MA dissertation, Universitetet i Oslo.

Remacle, Louis. 1948. Le problème de l'ancien wallon. Liège: Faculté de Philosophie et Lettres.

Rodríguez Somolinos, Amalia (éd), 2013, Marques d'oralité en français médiéval, Diachroniques 3.

Rowlett, Paul A. 2013. Do French speakers really have two grammars? Journal of French Language Studies 23,1: 37-57.

https://doi.org/10.1017/s095926951200035x

Salvesen, Christine Meklenborg \& Kristin Bech. 2014. Post-verbal subjects in Old English and Old French. Oslo Studies in Language (OSLa) 6,1: 201-228.

https://doi.org/10.5617/osla.725

Schøsler, Lene. 2002. La variation linguistique: le cas de l'expression du sujet. In Rodney Sampson \& Wendy Ayres-Bennett (eds), Interpreting the history of French: A Festschrift for Peter Rickard on the occasion of his eightieth birthday, 195-212. Amsterdam: Rodopi.

Skårup, Povl. 1975. Les premières zones de la proposition en ancien français. Essai de syntaxe de position. Copenhagen: Akademisk forlag. 
Steiner, Brittany D. J. 2014. The evolution of information structure and verb second in the history of French. PhD dissertation, Indiana University.

Thiersch, Craig. 1978. Topics in German syntax. PhD dissertation, MIT.

Vance, Barbara. 1997. Syntactic change in Medieval French. Verb-Second and Null Subjects. Dordrecht: Kluwer. https://doi.org/10.1007/978-94-015-8843-0

Wolfe, Sam. 2018. Verb Second in Medieval Romance. Oxford: Oxford University Press. https://doi.org/10.1093/oso/9780198804673.001.0001

Zribi-Hertz, Anne. 2011. Pour un modèle diglossique de description du français: quelques implications théoriques, didactiques et méthodologiques. Journal of French Language Studies 21,2: 231-256. https://doi.org/10.1017/s0959269510000323 